\title{
Validity and reliability study for Turkish adaptation of water balance questionnaire
}

Su dengesi ölçeği'nin Türkçe'ye uyarlanması geçerlik ve güvenirlik çalışması

\author{
Nilüfer ŞEN ${ }^{1 @(D)}$, Şule AKTAÇ ${ }^{1}$ \\ ${ }^{1}$ Marmara University, Faculty of Health Sciences, Department of Nutrition and Dietetics, 34854, İstanbul-Turkey
}

Atıf gösterme/Cite this article as: Şen N, Aktaç Ş. Validity and reliability study for Turkish adaptation of water balance questionnaire. ADYÜ Să̆llk Bilimleri Derg. 2021;7(2):120-128. doi:10.30569.adiyamansaglik. 859222

\begin{abstract}
Aim: The aim is to adapt the Water Balance Questionnaire (WBQ), to Turkish society, assess its validation and reproducibility.

Materials and Methods: 301 healthy adult individuals were included in the methodological study. First, linguistic equivalence was ensured, and expert opinions were obtained before piloting. For validation, 24-hour dietary recall (24HR), urine $\mathrm{pH}$ and urine specific gravity (USG) were used. To assess reliability, it was administered twice with a two-week interval.

Results: The questionnaire had strong and significant correlation with $24 \mathrm{HR}(\mathrm{r}=0.771 ; p<0.001)$, and strong, negative, and significant correlation with USG ( $\mathrm{r}=-$ $0.630 ; p<0.001)$, and strong, positive and significant correlation with urine $\mathrm{pH}(\mathrm{r}=0.604 ; p<0.001)$. The testretest correlation was 0.98 .

Conclusion: The WBQ, is a valid and reliable questionnaire. In the future, studies can be conducted to determine the hydration status of larger populations and groups suffering from dehydration by using WBQ. Keywords: Water intake; Water loss; Water balance; Validity and reliability; Hydration.
\end{abstract}

\section{$\ddot{\mathbf{O}} \mathbf{z}$}

Amaç: Bu çalışmada Su Dengesi Ölçeği’ni (SDÖ) Türk toplumuna uyarlamak, validasyonu ve tekrar elde edilebilirliğini değerlendirmek amaçlanmıştır.

Gereç ve Yöntem: Metodolojik tipteki bu çalışmaya 301 sağlıklı yetişkin birey katılmıştır. İlk aşamada ölçeğin dil eşdeğerliği sağlanıp uzman görüşleri alınmış, ardından pilot uygulama yapılmıştır. Validasyan aşamasında 24 saatlik geriye dönük besin tüketim kayd1, idrar $\mathrm{pH}^{\prime} 1$ ve idrar özgül ağırlığı kullanılmıştır. Güvenirliğin değerlendirilmesinde ölçek örnekleme 2 hafta ara ile ikinci kez uygulanmıştır.

Bulgular: Ölçek ile yirmi dört saatlik geriye dönük besin tüketim kaydı arasında güçlü düzeyde $(\mathrm{r}=0,771$; $p<0,001$ ), idrar özgül ağırlığı ile negatif yönde, güçlü düzeyde $(\mathrm{r}=-0,630 ; p<0,001)$, idrar $\mathrm{pH}$ 's1 ile pozitif yönde, güçlü düzeyde $(\mathrm{r}=0,604 ; p<0,001)$ anlamlı ilişki olduğu belirlenmiştir. Ölçeğin test-tekrar test korelasyonu 0,98 olarak bulunmuştur.

Sonuç: Su Dengesi Ölçeği, genel popülasyon için geçerli ve güvenilir bir ölçektir, SDÖ kullanılarak daha geniş popülasyonlar ve dehidrasyondan muzdarip grupların hidrasyon durumunun saptanabileceği çalışmalar yapılabilecektir.

Anahtar Kelimeler: Su alımı; Su kaybı; Su dengesi; Geçerlilik ve güvenilirlik; Hidrasyon.

Yazışma Adresi/Address for Correspondence: Nilüfer ŞEN, Marmara University, Faculty of Health Sciences, Department of Nutrition and Dietetics, 34854, İstanbul-Turkey, E-mail: nsen397@gmail.com

Geliş Tarihi/Received:12.01.2021 Kabul Tarihi/Accepted:19.05.2021

Yayım Tarihi/Published online:30.08.2021

Bu eser, Creative Commons Atıf-GayriTicari 4.0 Uluslararası Lisansı ile lisanslanmıștır. Telif Hakkı @ 2021 Adıyaman Üniversitesi Rektörlüğü 


\section{Introduction}

Euhydration defines the state of body water content at the optimal level of 280-290 $\mathrm{mOsmol} / \mathrm{kg}$ and urine specific gravity optimal level of $1.005-1.030 \mathrm{~g} / \mathrm{cm}^{3}$. ${ }^{1}$ Research has demonstrated that euhydrated individuals are associated with a low rate of mortality from coronary heart disease and a low risk of developing kidney stones. ${ }^{2,3}$ Euhydration has been further reported to reduce urolithiasis, the incidence of constipation, and the risk of exercise-induced asthma. $^{4}$ It has been reported that mild dehydration that occurs due to changes in body water balance may cause thirst, fatigue, weakness, dry mouth, sleepiness, agitation, and decreased concentration, while moderate dehydration may lead to thirst, fatigue, headache, incoordination, dyspnea and cognitive dysfunctions and severe dehydration to delirium, coma and death. 5,6,7 Therefore, dehydration assessment is highly important in terms of individual and public health. ${ }^{8}$ The literature contains very limited information on the daily water requirement for various populations as well as the hydration level required for the prevention and treatment of chronic diseases and urinary system infections. ${ }^{7,9-11}$ This is due to the facts that hydration is affected by several confounding factors, that there is no measurement method considered as gold standard for an accurate determination of hydration, and that the available methods are not cost-effective and require time. ${ }^{10-12}$ The European Food Safety Authority (EFSA) has indicated the need for a practical, low-cost and non-invasive tool for hydration assessment. ${ }^{11}$

Malisova et al. were the first to develop a Water Balance Questionnaire (WBQ), which is a practical and non-invasive screening tool to determine the water balance by identifying individuals water loss from sweating, defecation and urination, and water from beverages, foods and drinking water, and reported the WBQ to be a valid and reliable tool. ${ }^{8}$ Recently, there has been an increasing number of studies intended to establish hydration and its relationship with health in various populations in several countries upon the increased contribution of fluids to daily energy intake worldwide, the better understanding of the impact of euhydration on prevention of diseases and its significant role in treatment and maintaining health status, and the development of screening tools for this purpose. ${ }^{13,15-17}$ However, there has been no study conducted yet in Turkey the general population or various groups, except for athletes in order to establish individuals' total daily water intake and hydration status, and there is no practical and cost-effective screening tool to determine individuals' total water intake and evaluate water loss and hydration state. $^{18}$

The present study aimed to adapt the WBQ, which can be used for preventive health services, treatment and scientific research on this matter to the Turkish population, and to assess the validity and reproducibility of the questionnaire.

\section{Materials and Methods}

\section{Type of research}

The population of this methodological study consisted of individuals working at a medical center in Istanbul province, and individuals presenting at the medical center for checkup. The WBQ and urine analyses were administered under similar weather conditions in the same medical center at Istanbul. The average temperature during the two periods that the repeatability testing and validity occurred was $4.6^{\circ} \mathrm{C}$ (T.C. Ministry of Agriculture and Forest, General Directorate of Meteorology, Istanbul, Turkey).

\section{The universe and sample of the research}

The study sample was determined by simple random sampling, and the study was conducted between December 2018 and January 2020. As reported in the literature, a sample size of minimum 300 is required for a valid and reliable scale and a minimum 30 pairs of data is required for test-retest reliability assessment. ${ }^{19}$ A power analysis was made to determine the sample size, revealing that a minimum sample size of 258 was required for the correlation between two qualitative variables at a minimum level of 0.200 (weak) to be statistically significant at $\alpha=0.05$ and with a power of $90 \%$. 
Accordingly, the study included 330 individuals aged 18-60 years, who did not have diabetes, cancer, liver diseases, kidney diseases, hypertension, cardiovascular diseases or gastrointestinal diseases, who had not made any significant dietary changes for the last six months, who were not using any hypertensive, diuretic or antibiotics, who were not alcohol consumers of high levels ( 2 and 3 units for femeles and males, respectively), who did not have cold, flu and fever, who did not have any urinary system disease and who agreed to participate in the study. A total of 29 individuals who had failed anthropometric measurements $(n=2)$, provided incomplete or incorrect responses to questions $(n=6)$ and were identified to have urinary tract infection $(n=21)$ were excluded. As a result, the study sample consisted of 301 participants with 96 (31.9\%) males and $205(68.1 \%)$ females. Table 1 presents descriptive characteristics of the study participants.

Table 1. Sample characteristics.

\begin{tabular}{lcccccc}
\hline & \multicolumn{2}{c}{ Male $(\mathrm{n}=96)$} & \multicolumn{2}{c}{ Female $(\mathrm{n}=205)$} & \multicolumn{2}{c}{ Total sample } \\
\cline { 2 - 7 } & mean \pm SD & min-max & mean \pm SD & min-max & mean \pm SD & $\min -\max$ \\
\hline Age $($ year $)$ & $35.7 \pm 11.9$ & $18-59$ & $37.1 \pm 12.2$ & $18-59$ & $36.7 \pm 12.1$ & $18-59$ \\
Height $(\mathrm{cm})$ & $180.0 \pm 0.1$ & $158.0-190.0$ & $160.0 \pm 0.1$ & $150.0-180.0$ & $165.0 \pm 0.1$ & $149.0-190.0$ \\
Weight $(\mathrm{kg})$ & $80.4 \pm 9.1$ & $60.0-102.0$ & $64.4 \pm 10.2$ & $43.0-95.0$ & $69.5 \pm 12.4$ & $43.0-102.0$ \\
BMI $\left(\mathrm{kg} / \mathrm{m}^{2}\right)$ & $26.0 \pm 2.9$ & $20.3-33.9$ & $25.4 \pm 4.5$ & $15.6-40.5$ & $25.6 \pm 4.1$ & $15.6-40.5$ \\
\hline
\end{tabular}

Food frequency questionnaire (FFQ), diet history questionnaire, isotope analyses and biochemical markers have been recommended for use as a reference method to assess validity in studies on nutrition. ${ }^{20,21}$ To assess the validity of the Turkish adaptation of the WBQ, a 24HR, urine $\mathrm{pH}$ and urine specific gravity (USG) were used. First, the WBQ was administered to the participants at the first interview, and then the 24HR and urine samples were collected; participants' body weight and height were measured (Body Composition Analyser Tanita/MC 780 ST, Leister Height measure, Corporation of America, Arlington Heights, IL, USA) and body mass index (BMI) were calculated. Within the scope of test-retest for the assessment of questionnaire reliability, the participants were administered the WBQ for the second time using the face-to-face interview method two weeks after each participant's first interview.

\section{Data collection tools}

\section{Water balance questionnaire}

It was designed to be comprehensive, explicit, short, simple and non-perplexing as well. The WBQ included a series of questions regarding: (a) the profile of the individual; (b) consumption of solid and fluid food; (c) drinking water or beverage intake; (d) physical activity; (e) sweating; (f) urination and defecation and $(\mathrm{g})$ trends on fluid and water intake. Water balance is calculated by subtracting total water loss (sweating, defecation, urination) from total water intake (water from beverages, water from foods, water from drinking water). The body water intake from foods and beverages was determined using a food frequency questionnaire and a beverage consumption beverage frequency questionnaire, and the water content of foods was determined using the 'Nutrition Information System' (BeBIS 8.1, Blue Apple Software, Istanbul, Turkey), which is a computer-aided nutritional program developed for Turkey. Details of the WBQ has been explained in the study of Malisova et al. ${ }^{8}$

\section{Urine biomarkers}

Urine samples of the participants were collected between 09.00-10.00 A.M. at as their first urine in the morning minimum 50 $\mathrm{ml}$ in a $100 \mathrm{ml}$ sterile containers, and analyzed immediately using urinalysis strips (ACON Insight Xpert, San Diego, CA, USA). Urine specific gravity and $\mathrm{pH}$ were evaluated based on the reference values of 1.005-1.030 $\mathrm{g} / \mathrm{cm}^{3}$ and 5-8, respectively that were used at the medical center's laboratory. In dehydration state, urine specific gravity increases above $1.030 \mathrm{~g} / \mathrm{cm}^{3}$ and urine $\mathrm{pH}$ decreases below 5. ${ }^{1}$ The urine biomarker values were found to be within physiological range for all participants (Table 2). 
Table 2. Biochemical urine markers characteristics.

\begin{tabular}{lcccccc} 
& \multicolumn{2}{c}{ Male $(\mathrm{n}=96)$} & \multicolumn{2}{c}{ Female $(\mathrm{n}=205)$} & \multicolumn{2}{c}{ Total sample } \\
\cline { 2 - 7 } & mean \pm SD & min-max & mean \pm SD & min-max & mean \pm SD & min-max \\
\hline $\begin{array}{l}\text { Urine specific gravity } \\
\left(\mathrm{g} / \mathrm{cm}^{3}\right)\end{array}$ & $1019.3 \pm 7.5$ & $1006-1030$ & $1017.8 \pm 5.8$ & $1006-1030$ & $1018.3 \pm 6.4$ & $1006-1030$ \\
Urine $\mathrm{pH}$ & $6.1 \pm 0.6$ & $5.0-7.2$ & $6.1 \pm 0.4$ & $5.1-7.4$ & $6.1 \pm 0.5$ & $5.0-7.4$ \\
\hline
\end{tabular}

\section{Twenty four-hour dietary recall}

The daily water intake of study participants was determined through the $24 \mathrm{HR}$. The water from foods and beverages was calculated using BeBIS 8.1.

\section{Data analysis}

Statistical analyses were performed using the Number Cruncher Statistical System 2007 (NCSS; Kaysville, Utah, USA) program. The Pearson correlation analysis was used to evaluate the associations between quantitative variables. The strength of correlation was evaluated using Evans'classification. Test and retest measurements were compared using the dependent samples t-test, and the Pearson correlation analysis was used to establish the extent of the correlation between test and retest measurements. The agreement between test and retest measurements was analyzed using the Bland-Altman plots. A p value of $<0.05$ was considered statistically significant.

\section{Ethical aspect of the research}

The study protocol was approved by Relevant University Faculty of Medicine Clinical Research Ethics Committee (Ethics Committee Number: 09.2018.785). Institutional permission was obtained from the center where the study was conducted.

\section{Results}

\section{Equivalance of language and content validity}

For the linguistic equivalence of the questionnaire, first the necessary permission was obtained from the researchers who developed the questionnaire. The linguistic equivalence of the questionnaire was provided using the standard translation-back translation method, as reported to be an effective method in the literature. ${ }^{22}$ During the translation step, the original questionnaire was translated into Turkish by three individuals who could speak both languages fluently, were familiar with the culture involved in the research and had knowledge of the constructs to be measured. Then, the items from three Turkish versions were compared, and the items with same translation were identified, resulting in the draft version. Subsequently, the questionnaire was translated from Turkish back into English by two individuals who had good command of both languages and who were living abroad. The original questionnaire and the one translated back to English were compared, and were found to be in agreement. Foods not consumed by the Turkish population (pork meat and bacon), traditional Greek dishes (gigandes plaki, sesame-covered Thessaloniki bread, pastitsio, anthotyro and manouri) and beverages (Greek coffee, milkshake and sorbet) in the food frequency and beverage frequency sections of the WBQ were removed from the questionnaire. Instead, food commonly consumed by Turkish population but not included in the questionnaire Turkish bagel, corn bread, flatbread, lahvash, soujouk, pastrami, giblets, tarhana, lentil, ezogelin soup, lentil patties, Turkish bulgur salad, Turkish noodles, Turkish type ravioli, kebabs, stews, dates, burek and other pastries, halvas, syrup sweets, molasses and tahini) and beverages specific to the country (sahlep, Turkish coffee, ayran, kefir, boza and turnip juice) were added to the proper sections by considering their water content provided in the TürKomp (National Food Composition Database) and BeBIS databases. Portions of the foods and beverages included in the questionnaire were based on the portions specified in the Turkish Guidelines on Nutrition. ${ }^{23}$

The questionnaire that was finalized according to the expert opinion was administered to 30 individuals who were representatives of the target population, met the study inclusion criteria and were not included in the study sample, and comprehensibility of the items was examined through questions such as "What do you think this question asks?" or "What does this 
question mean?". After the pilot study, some statements were simplified and the response time for the questionnaire was found to be $10-15$ minutes.

For the content validity assessment of the WBQ, seven experts were asked to provide their opinion on the questionnaire and expert opinions were evaluated using the Content Validity Index (CVI). A CVI higher than 0.80 was considered acceptable for content validity. ${ }^{24}$ The total CVI of the Turkish version of the WBQ was 0.86. Turkish of WBQ is rendered as a supplement.

\section{Validity of WBQ}

The validity of the WBQ was evaluated by analyzing the correlation between the water balance from the questionnaire, and USG and pH. Accordingly, as shown in Table 3, there was a strong negative correlation between water balance and USG values ( $\mathrm{r}=-0.630$, $p<0.001$ ), and a strong positive correlation between water balance and urine $\mathrm{pH}$ values $(\mathrm{r}=0.604 ; p<0.001)$. When the correlation between the WBQ and the 24HR was examined, there was a very strong positive correlation with water from beverages and drinking water (for drinking water and beverages, $\mathrm{r}=0.988, \mathrm{r}=0.954$, respectively; $p<0.001$ ), a weak positive correlation with water from foods $(\mathrm{r}=0.398 ; p<0.001)$ and a strong positive correlation with total water intake $(\mathrm{r}=0.771 ; p<0.001)$ (Table 4).

Table 3. Relationship between WBQ and biochemical urine markers

\begin{tabular}{|c|c|c|}
\hline \multirow{2}{*}{ Urine markers } & \multicolumn{2}{|c|}{ Water balance } \\
\hline & $\mathrm{r}$ & $p$ \\
\hline Urine specific gravity & -0.630 & $<0.001 *$ \\
\hline Urine $\mathrm{pH}$ & 0.604 & $<0.001 *$ \\
\hline
\end{tabular}

Table 4. Relationship between WBQ and 24-hour dietary recall

\begin{tabular}{lcc}
\hline \multirow{2}{*}{ 24-hour dietary recall } & correlation with questionnaire \\
\cline { 2 - 3 } Total (n=301) & $\mathrm{r}$ & $p$ \\
Water total consumption (ml/day) & 0.771 & $<0.001^{*}$ \\
Water from foods (ml/day) & 0.398 & $<0.001^{*}$ \\
Water from liquids (ml/day) & 0.988 & $<0.001^{*}$ \\
Water from water (ml/day) & 0.954 & $<0.001^{*}$ \\
Male (n=96) & & $<0.001^{*}$ \\
Water total consumption (ml/day) & 0.950 & $<0.001^{*}$ \\
Water from foods (ml/day) & 0.996 & $<0.001^{*}$ \\
Water from liquids (ml/day) & 0.996 & $<0.001^{*}$ \\
Water from water (ml/day) & 0.927 & $<0.001^{*}$ \\
Female (n=205) & & $<0.001^{*}$ \\
Water total consumption (ml/day) & 0.703 & $<0.001^{*}$ \\
Water from foods (ml/day) & 0.336 & $<0.001^{*}$ \\
Water from liquids (ml/day) & 0.985 & \\
Water from water (ml/day) & 0.965 & \\
\hline Pearson correlation analysis, ${ }^{*} p<0.001$ r: pearson correlation coefficient & &
\end{tabular}

The water from beverages from the questionnaire was statistically significantly greater than the water from beverages from 24HR (712.2. L vs. 681.7 L, $p<0.001)$. There was no statistically significant difference between total water intake (foods, beverages, drinking water) from the WBQ and total water intake (foods, beverages, drinking water) from the 24HR $(p>0.05)$ (Table 5).

\section{Reliability of WBQ}

The reliability of the WBQ was evaluated through test-retest comparison, and the results are provided in Table 6. Accordingly, there was no statistically significant difference in total water intake, water from foods, water from beverages, water from drinking water, body water loss and body water balance between the two measurements $(p>0.05)$. The test-retest correlation analysis revealed a very strong positive correlation between total water intakes $(\mathrm{r}=0.985 ; p<0.001)$, a very strong positive correlation between water from foods $(\mathrm{r}=0.996 ; p<0.001)$, a very strong positive correlation between water from beverages $(\mathrm{r}=0.997 ; p<0.001)$, a very strong positive correlation between consumptions of drinking water $(\mathrm{r}=0.984 ; p<0.001)$, a very strong positive correlation between body water loss amounts $(\mathrm{r}=0.950 ; p<0.001)$ and between 
body water balance values $(\mathrm{r}=0.954 ; \quad p<0.001)$.

Table 5. Comparison of WBQ and 24-hour dietary recall.

\begin{tabular}{lcccc}
\hline & WBQ & 24-hour dietary recall & difference & $p$ \\
\hline Total (n=301) & & & & \\
\hline Water total consumption (ml/day) & $2821.6 \pm 610.2$ & $2774.8 \pm 794.3$ & $46.8 \pm 505.8$ & 0.109 \\
Water from foods (ml/day) & $768.3 \pm 183.0$ & $748.0 \pm 510.0$ & $20.3 \pm 468.3$ & 0.452 \\
Water from liquids (ml/day) & $712.2 \pm 360.5$ & $681.7 \pm 361.0$ & $30.5 \pm 54.8$ & $<0.001 *$ \\
Water from water (ml/day) & $1341.0 \pm 579.1$ & $1345.1 \pm 598.5$ & $-4.1 \pm 180.5$ & 0.697 \\
\hline Male (n=96) & & & & $<0.001 *$ \\
\hline Water total consumption (ml/day) & $2753.7 \pm 704.6$ & $2842.9 \pm 642.1$ & $-89.2 \pm 221.9$ & $<0.001 *$ \\
Water from foods (ml/day) & $723.9 \pm 190.6$ & $678.9 \pm 190.5$ & $45.0 \pm 16.8$ & $<0.001 *$ \\
Water from liquids (ml/day) & $696.7 \pm 371.9$ & $725.8 \pm 372.0$ & $-29.1 \pm 34.0$ & 0,499 \\
Water from water (ml/day) & $1378.1 \pm 582.4$ & $1393.2 \pm 544.7$ & $-15.1 \pm 218.1$ & \\
\hline Female (n=205) & & & & 0.516 \\
\hline Water total consumption (ml/day) & $2784.6 \pm 834.5$ & $2811.6 \pm 596.1$ & $-26.9 \pm 593.3$ & 0,824 \\
Water from foods (ml/day) & $789.1 \pm 176.0$ & $780.3 \pm 601.8$ & $8.8 \pm 567.4$ & $<0.001 *$ \\
Water from liquids (ml/day) & $674.7 \pm 356.6$ & $705.9 \pm 355.7$ & $-31.2 \pm 62.2$ & $<2.244$ \\
Water from water (ml/day) & $1329.6 \pm 606.6$ & $1316.6 \pm 594.2$ & $13 \pm 159.6$ & 0.244 \\
\hline Samples t-test, * $p<0.001$ & & & &
\end{tabular}

Table 6. Results of the reliability procedure.

\begin{tabular}{lcccc}
\hline & $\begin{array}{c}\text { First recording } \\
\text { of the WBQ }\end{array}$ & $\begin{array}{c}\text { Second recording } \\
\text { of the WBQ }\end{array}$ & difference & $p$ \\
\hline Total (n=301) & & & & \\
Water total consumption(ml/day) & $2821.6 \pm 610.2$ & $2824.7 \pm 615.5$ & $3.1 \pm 89.8$ & 0.547 \\
Water from foods (ml/day) & $768.3 \pm 183.0$ & $769.6 \pm 183.9$ & $1.3 \pm 11.4$ & 0.051 \\
Water from liquids (ml/day) & $712.2 \pm 360.5$ & $712.2 \pm 360.5$ & $0.00 \pm 0.00$ & 0.999 \\
Water from water (ml/day) & $1341.0 \pm 579.1$ & $1342.9 \pm 583.6$ & $1.8 \pm 89.1$ & 0.722 \\
Water loss (ml/day) & $2001.3 \pm 675.4$ & $1999.7 \pm 692.2$ & $-1.6 \pm 224.8$ & 0.900 \\
Water balance (ml/day) & $820.2 \pm 800.1$ & $824.9 \pm 798.1$ & $4.8 \pm 242.4$ & 0.734 \\
Male (n=96) & & & & \\
Water total consumption (ml/day) & $2842.9 \pm 642.1$ & $2838.9 \pm 650.2$ & $4.1 \pm 62.9$ & 0.529 \\
Water from foods (ml/day) & $723.9 \pm 190.6$ & $726.1 \pm 191.4$ & $-2.2 \pm 13.3$ & 0.109 \\
Water from liquids (ml/day) & $725.8 \pm 372$ & $725.8 \pm 372$ & $6.3 \pm 61.2$ & 0.320 \\
Water from water (ml/day) & $1393.2 \pm 544.7$ & $1387 \pm 554.9$ & $28.5 \pm 328.7$ & 1.000 \\
Water loss (ml/day) & $2101.9 \pm 836.2$ & $2073.4 \pm 834.7$ & $-24.4 \pm 335.0$ & 0.398 \\
Water balance (ml/day) & $741 \pm 940.7$ & $765.4 \pm 910.8$ & $4.1 \pm 62.9$ & 0.477 \\
Female (n=205) & & & & \\
Water total consumption (ml/day) & $2811.6 \pm 596.1$ & $2818.1 \pm 600.1$ & $-6.5 \pm 99.9$ & 0.354 \\
Water from foods (ml/day) & $789.1 \pm 176$ & $790 \pm 177.2$ & $-0.9 \pm 10.5$ & 0.236 \\
Water from liquids (ml/day) & $705.9 \pm 355.7$ & $705.9 \pm 355.7$ & $-5.6 \pm 99.4$ & 1.000 \\
Water from water (ml/day) & $1316.6 \pm 594.2$ & $1322.2 \pm 596.7$ & $-10.9 \pm 153.3$ & 0.420 \\
Water loss (ml/day) & $1954.2 \pm 581.5$ & $1965.2 \pm 613.5$ & $4.5 \pm 184.1$ & 0.308 \\
Water balance (ml/day) & $857.3 \pm 724.5$ & $852.9 \pm 740.2$ & $-6.5 \pm 99.9$ & 0.729 \\
\hline Samples t-test $p<0.0$ & & & &
\end{tabular}

Figure presents the Bland-Altman plots for the test-retest data of the WBQ. Accordingly, the average values were close to zero and the test-retest differences were within the limits of agreement, except for a few outliers. Concordantly, there was an agreement between test and retest measurements.

\section{Discussion}

The present study was carried out on the Turkish adaptation of the WBQ developed by Malisova et al., as well as the validity and reliability analyses. The review of literature shows that dietary recall have been used as a reliable method in the validation studies of FFQ, beverage intake questionnaires (BIQ) and WBQ. ${ }^{17,}{ }^{25}$ The study by Malisova et al. for the development of the original questionnaire reported that the daily water intake from the questionnaire $(1.920 \pm 35.5 \mathrm{ml})$ was significantly lower than the daily water intake from the three-day food intake record $(2.264 \pm 79 \mathrm{ml}) .{ }^{8}$ Karabudak and Köksal's Turkish adaptation study for the BIQ reported that the water intake from the $24 \mathrm{HR}$ $(1.120 \pm 49.5 \mathrm{ml} /$ day $)$ was lower than the water 
intake from the questionnaire $(1.990 \pm 46.3$ $\mathrm{ml} /$ day). ${ }^{24}$ Likewise, the present study found that the water intake from foods and beverages from the WBQ was higher than the water intake from the 24HR. While the present study established a strong correlation

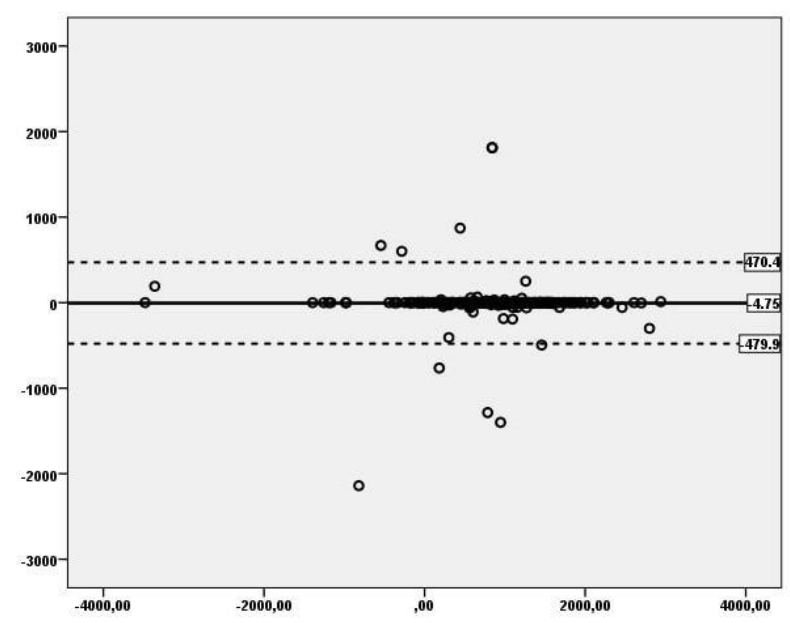

Figure 1.1 Average from water balance of both administrations

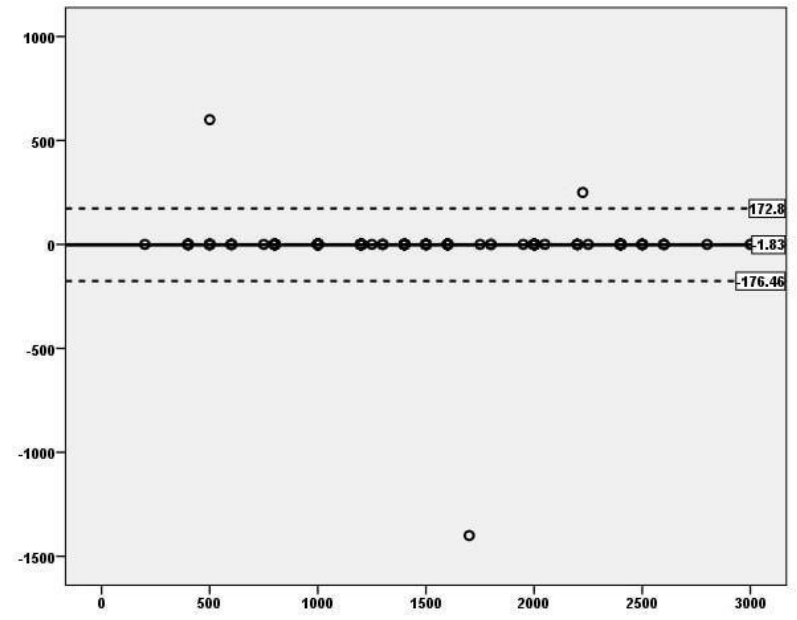

Figure 1.3 Average from drinking water of both administrations

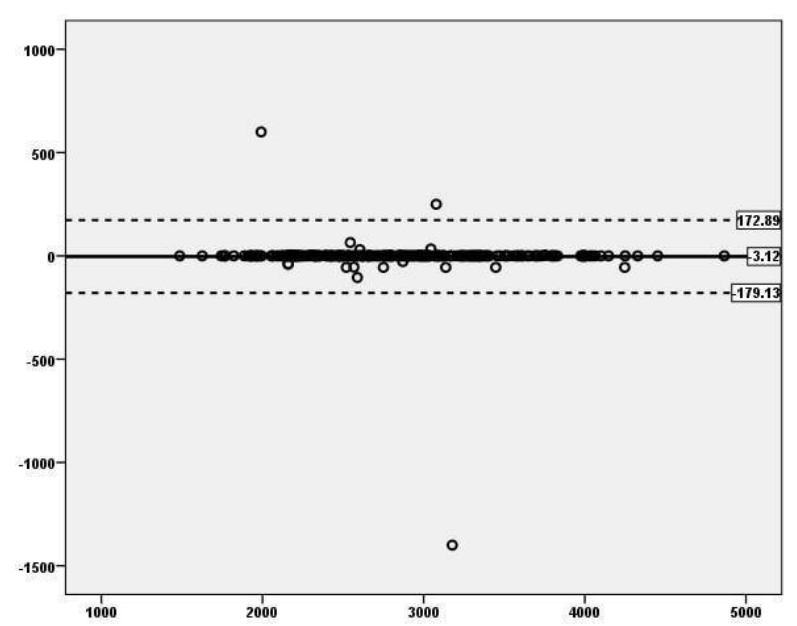

Figure 1.5 Average from total water intake of both administrations between total water intakes from the questionnaire and from the 24HR, Karabudak and Köksal similarly demonstrated a very strong correlation between all beverage intakes on the assessment tool, except for alcoholic beverage intake. ${ }^{24}$

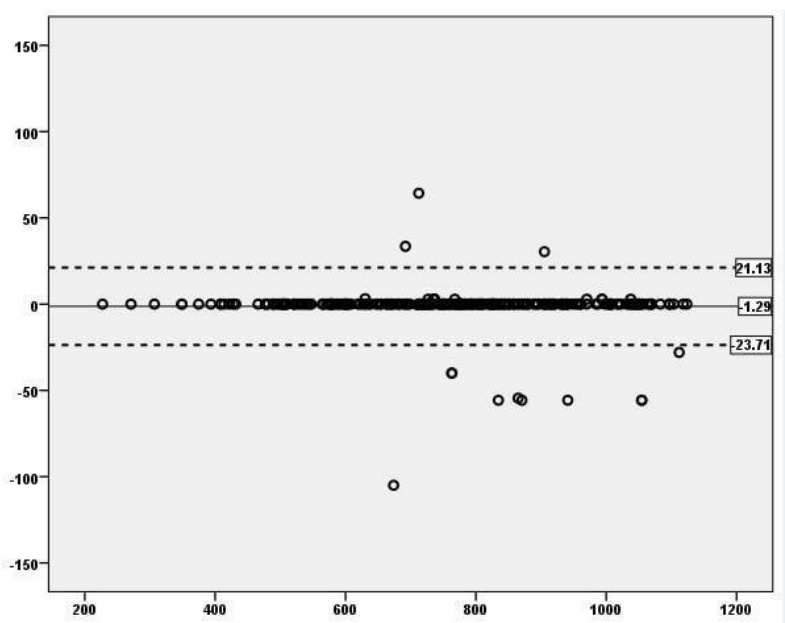

Figure 1.2 Average from water from foods of both administrations

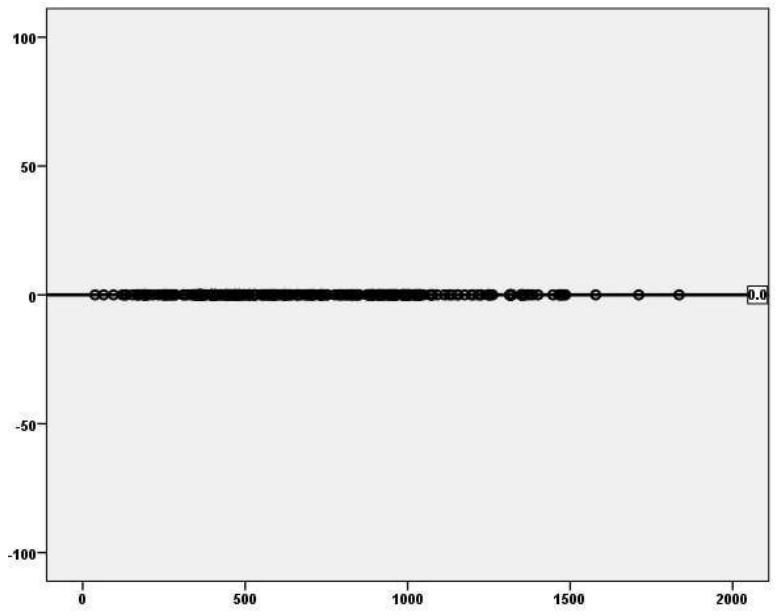

Figure 1.4 Average of water from beverages of both administrations

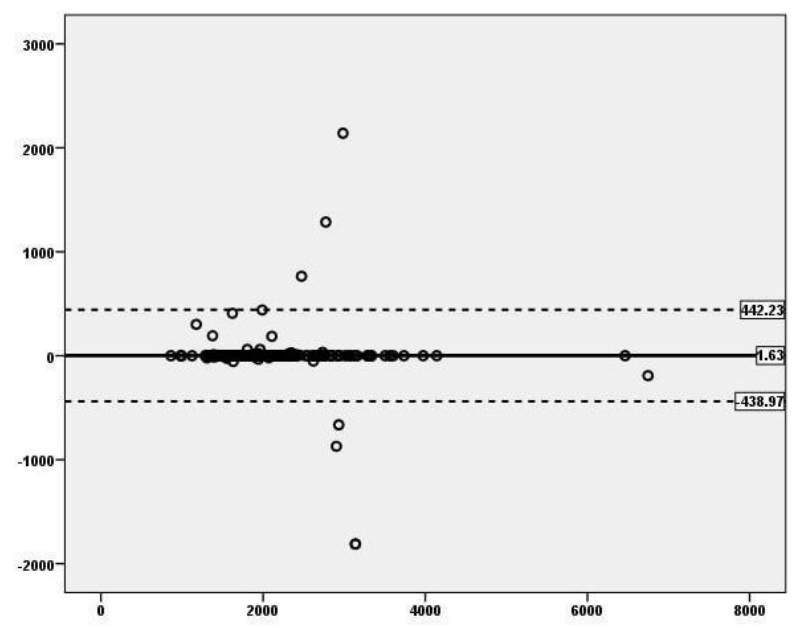

Figure 1.6 Average from water loss of both administrations 
When compared with the $24 \mathrm{HR}$, the Turkish adaptation of the WBQ was found to accurately determine water from foods, beverages and drinking water.

When the water balance from the questionnaire and the urinary biomarkers were compared as part of the validity assessment of the Turkish adaptation of the WBQ, there was a strong positive correlation between water balance from the questionnaire and urine $\mathrm{pH}$ values, and a strong negative correlation between water balance from the questionnaire and USG values. Malisova et al. in turn, did not establish any correlation between water balance, and USG and urine pH values. ${ }^{8}$ Hedrick et al. and Karabudak and Köksal reported a weak negative correlation between USG and fluid intake. When compared with USG and $\mathrm{pH}$, the Turkish adaptation of the WBQ was found to accurately determine water balance. ${ }^{26,27}$

As part of the reliability analysis of the Turkish adaptation of the WBQ, test-retest reliability was evaluated to establish time invariance. In line with the literature, the questionnaire was re-administered to the study sample at two weeks intervals, and the correlation between the two measurements was evaluated. Accordingly, no statistically significant difference was established in participants' total water intake, water from foods, water from beverages, water from drinking water, body water loss and body water balance between two measurements, as in the studies by Malisova et al. ${ }^{8,24}$

Some limitations exist in this investigation. Firstly, participants completed the selfadministrated WBQ and 24HR. So subjects were prone to underestimate their beverage and food intake when they kept dietary records. Secondly, no clinical and practical method in the literature determines the hydration status through feces and sweat. Therefore, only urine biomarkers were used. Thirdly, there isn't a gold standard method assessing hydration status in the literature. This suggests that a combination of indices may be appropriate in depicting hydration status. In this study, urine specific gravity and $\mathrm{pH}$ methods are used.

\section{Conclusion}

In conclusion, the Turkish adaptation of the WBQ is a valid and reliable tool to evaluate individuals' water balance, water intake, water loss and fluid consumption habits. In this way, it can identify nutritional reasons that cause dehydration. The Turkish version of WBQ can be used to evaluate the effectiveness of hydration in the prevention and treatment of diseases. It is a device-free, practical and fast method that can be used to determine the effectiveness of hydration strategies and hydration education interventions used to prevent dehydration, especially in groups at risk of dehydration (athletes, the elderly, heavy workers).

\section{Ethics Committee Approval}

The study protocol was approved by Relevant University Faculty of Medicine Clinical Research Ethics Committee (Ethics Committee Number: 09.2018.785). Institutional permission was obtained from the center where the study was conducted.

\section{Informed Consent}

All participants signed the Informed Consent Form and their consent was obtained.

\section{Author Contributions}

Idea, design, collection of resources, analysis and interpretation of results and literature, written and critical: NŞ and ŞA.

\section{Acknowledgments}

We thank all the participants who agreed to participate in the research for their sincere sharing.

\section{Conflict of Interest}

There is no conflict of interest among the authors.

\section{Financial Disclosure}

There is no financial disclosure.

\section{Statements}

This article was from a thesis, "Validity and Reliability Study for Turkish Adaptation of Water Balance Questionnaire, for General Population' done on 09/03/2020 at Relevant University. The article is not under 


\section{publication or consideration for publication elsewhere}

\section{Peer-review}

\section{Externally peer-reviewed.}

\section{References}

1. Williamson MA, Snyder LM. Wallach's interpretation of diagnostic tests. 9st ed. Lippincott W \& Wilkins: Philadelphia, USA; 2011

2. Welch K. Fluid balance. Learning Disability Practice.2010;13(6):33-38.

3. Strippoli GF, Craig JC, Rochtchina E, Flood VM, Wang JJ, Mitchell P. Fluid and nutrient intake and risk of chronic kidney disease. Nephrology (Carlton). 2011;16(3):326-34. doi: 10.1111/j.1440-1797.2010.01415.x

4. Popkin BM, D'Anci KE, Rosenberg IH. Water, hydration, and health. Nutr Rev. 2010;68(8):439-58. doi:10.1111/j.17534887.2010.00304.x.

5. Pross N, Demazieres A, Girard $\mathrm{N}$, et al. Influence of progressive fluid restriction on mood and physiological markers of dehydration in women. Br J Nutr. 2013;109:313-321. doi: 10.1017/S0007114512001080.

6. Adan A. Cognitive performance and dehydration. J Am Coll Nutr. 2012;31(2):71-8. doi: 10.1080/07315724.2012.10720011.

7. Watso JC, Farquhar WB. Hydration status and cardiovascular $\begin{array}{lll}\text { function. } & \text { Nutrients. }\end{array}$ 10.3390/nu11081866

8. Malisova O, Bountziouka V, Panagiotakos DB, Zampelas A, Kapsokefalou M. The water balance questionnaire: design, reliability and validity of a questionnaire to evaluate water balance in the general population. Int J Food Sci Nutr. 2012;63(2):138-44. doi: 10.3109/09637486.2011.607799.

9. El-Sharkawy AM, Sahota O, Lobo DN. Acute and chronic effects of hydration status on health. Nutr Rev. 2015;73(2):97109. doi: 10.1093/nutrit/nuv038.

10. Nissensohn M, Ruano C, Serra-Majem L. Validation of beverage intake methods vs. hydration biomarkers; a short review. Nutr Hosp. 2013;28(6):1815-9.

11. European Food Safety Association. Panel on Dietetic Products, Nutrition, and Allergies (NDA); Scientific Opinion on Dietary reference values for water. European Food Safety Association; 2010. Web site. http://www.efsa. europa.eu/en/efsajournal/pub/1459.htm. Accessed on 2 December 2020.

12. Armstrong LE, Johnson E. Water Intake, water balance, and the elusive daily water requirement. Nutrients. 2018;10(12):1928. doi: 10.3390/nu10121928.

13. Baron S, Courbebaisse M, Lepicard EM, Friedlander G. Assessment of hydration status in a large population. Br J Nutr. 2015;113(1):147-58. doi: 10.1017/S0007114514003213.

14. Gandy J, Le Bellego L, König J, Piekarz A, Tavoularis G, Tennant DR. Recording of fluid, beverage and water intakes at the population level in Europe. Br J Nutr. 2016;116(4):677-82. doi: $10.1017 /$ S0007114516002336.

15. Malisova O, Athanasatou A, Pepa A, et al. Water intake and hydration indices in healthy european adults: The european hydration research study (EHRS). Nutrients. 2016;8(4):204. doi: 10.3390/nu8040204.

16. Guelinckx I, Ferreira-Pêgo C, Moreno LA, et al. Intake of water and different beverages in adults across 13 countries. Eur J Nutr. 2015;2(2):45-55. doi: 10.1007/s00394-015-0952-8.

17. Laja García AI, Samaniego Vaesken ML, Partearroyo T, Varela Moreiras G. Validated questionnaire to assess the hydration status in a healthy adult Spanish population: a cross sectional study. Nutr Hosp. 2019;36(4):875-883. doi: 10.20960/nh.02533.

18. Demirkan E, Koz M, Kutlu M. The effects of dehydration on athletic performance and monitoring hydration levels. Spormetre The Journal Of Physical Education And Sport Sclences. 2010;8(3):81-92. doi: 10.1501/Sporm_0000000181

19. Clarke LA, Watson D. Constructing validity: basic issues in objective scale development. Pyschol Assess.1995;7:309-319. doi:10.1037/1040-3590.7.3.309.
20. Cade J, Thompson R, Burley V, Warm D. Development, validation and utilisation of food-frequency questionnaires - a review. Public Health Nutr. 2002;(4):567-87. doi: 10.1079/PHN2001318.

21. Uluğ E, Rakıcıoğlu N. Dietary Assessment of Micronutrients Intake.Bes Diy Derg. 2019;47(3):85-93.

22. Capık C, Gozum S, Aksayan S. Intercultural Scale Adaptation Stages, Language and Culture Adaptation: Updated Guideline. FNJN Florence Nightingale Journal of Nursing. 2018; 26: 199210. doi: 10.26650/fnjn397481.

23. Turkish Public Health Institution. Turkish Guidelines on Nutrition TÜBER-2015. Ankara, Turkey: Ministry of Health Publications;2016.

24. Grant JS, Davis LL. Selection and use of content experts for instrument development. Res Nurs Health. 1997;20(3):26974.doi: $\quad 10.1002 /($ sici)1098-240x(199706)20:3<269::aidnur9>3.0.co;2-g

25. Karabudak E, Koksal E. Validity and reliability of beverage intake questionnaire: evaluating hydration status. Nutr Hosp. 2016;33(5):577. doi: 10.20960/nh.577.

26. Hedrick VE, Comber DL, Estabrooks PA, Savla J, Davy BM. The beverage intake questionnaire: determining initial validity and reliability. J Am Diet Assoc. 2010;110(8):1227-32. doi: 10.1016/j.jada.2010.05.005.

27. Acemoğlu H, Aktürk Z. Reliability and validity in medical research. Dicle Medical Journal. 2012;39(2): 316-319. doi: 10.5798/diclemedj.0921.2012.02.01. 